the presence of acetone as the best method of forming chloroform, if some way were found to overcome the high resistance due to the deposits forming on the cathode.

CORNELL UNIVERSTTY,

February, Igo4.

\title{
RUTHENIUM, V. THE CHLORIDES (Continued).
}

BY JAS. LEWIS HUWE.

Received March 17. 1904.

IN A previous paper upon the chlorides of ruthenium ${ }^{1}$ there were described cesium and rubidium chlorruthenates, $\mathrm{Cs}_{2} \mathrm{RuCl}_{6}$ and $\mathrm{Rb}_{2} \mathrm{RuCl}_{B}$, and a so-called cesium "aquo" chlorruthenate, but at that time little had been learned of the conditions of formation of these salts. While no light has been thrown upon the peculiar origin of the particular chlorruthenates described in that paper, further study has shown a general method by which the chlorruthenates, $\mathrm{X}_{2} \mathrm{Ru}^{\mathrm{IV}} \mathrm{Cl}_{6}$, as well as the "aquo" chlorruthenates, can be prepared.

When a solution of ruthenium trichloride, prepared by the action of hydrochloric acid on either ruthenium tetroxide or the hydrated sesquioxide (that is, the ordinary ruthenium chloride) is boiled in very dilute solution with hydrochloric acid and alcohol, it gradually changes from its deep yellowish red color to a lighter and less yellow tint. If now it is evaporated with an alkaline chloride, it deposits crystals which may vary from the rose prisms described in the previous paper, to rich red crystals, somewhat resembling the ordinary crystals of the chlorruthenite $\left(\mathrm{X}_{2} \mathrm{Ru}^{\mathrm{III}} \mathrm{Cl}_{5}\right)$, but lighter in color and transparent. This change may be induced by other agents than alcohol, as oxalic acid and possibly stannous chloride. These crystals are the "aquo" chlorruthenate, the cesium salt of which was described in the previous paper. Their formula is $\mathrm{X}_{2} \mathrm{RuCl}_{5} \mathrm{H}_{2} \mathrm{O}$, but to distinguish them from the ordinary hydrated salts of the chlorruthenites, the formula may be written $\mathrm{X}_{2} \mathrm{Ru}\left(\mathrm{OH}_{2}\right) \mathrm{Cl}_{5}$.

The "aquo" chlorruthenates differ very markedly from the isomeric chlorruthenites. They are stable to $140^{\circ}$, but lose water rapidly at $180^{\circ}$, leaving the salt $\mathrm{X}_{2} \mathrm{RuCl}_{5}$. Crystals of the dehydrated potassium "aquo" chlorruthenate preserve the form of the

1 'rhis Journal, 23, 775 (rgor). 
aquo salt, with often fine reflecting surfaces, but except in thin sections, are opaque. Their solution differs wholly from that of the potassium chlorruthenite, with which it is isomeric, and gives the reactions for the original aquo salt. We thus appear to have two distinct salts of the formula $\mathrm{X}_{2} \mathrm{RuCl}_{5}$. In what the nature of this isomerism consists, we can hardly conjecture. It should be mentioned that while the ordinary potassium chlorruthenite is anhydrous, Miolati ${ }^{1}$ has obtained monohydrated crystals, $\mathrm{K}_{2} \mathrm{RuCl}_{5}, \mathrm{H}_{2} \mathrm{O}$, which are thus isomeric with, but distinct from, the aquo salt.

Mr. C. S. Lind ${ }^{2}$ was kind enough to compare the conductivity of the solutions of the chlorruthenite and the "aquo" chlorruthenate, and I am permitted to quote from his results. Both salts undergo a similar decomposition in water, accompanied by an increase in conductivity, but this increase is much slower in the case of the aquo salt. While the initial value of the conductivity is the same for the two salts, the final value for the aquo salt is much less than that for $\mathrm{K}_{2} \mathrm{RuCl}_{5}$. The final value for the latter corresponds to the equation

$$
\mathrm{K}_{2} \mathrm{RuCl}_{5}+2 \mathrm{H}_{2} \mathrm{O}=2 \mathrm{KCl}+2 \mathrm{HCl}+\mathrm{Ru}(\mathrm{OH})_{2} \mathrm{Cl}
$$

while the final value for the aquo salt approximates closely to the equation

$$
\mathrm{K}_{2} \mathrm{RuCl}_{5}+\mathrm{H}_{2} \mathrm{O}=2 \mathrm{KCl}+\mathrm{HCl}+\mathrm{Ru}(\mathrm{OH}) \mathrm{Cl}_{2}
$$

or

$$
\mathrm{K}_{2} \mathrm{Ru}\left(\mathrm{OH}_{2}\right) \mathrm{Cl}_{5}+\mathrm{H}_{2} \mathrm{O}=2 \mathrm{KCl}+\mathrm{HCl}+\mathrm{Ru}\left(\mathrm{OH}_{2}\right)(\mathrm{OH}) \mathrm{Cl}_{2} \text {. }
$$

The most distinguishing reaction of the aquo salt is that its solution is immediately darkened by the fumes of chlorine or bromine. This affords a ready means of identification, as the reaction is possessed by no other class of ruthenium salts as far as known. This reaction is caused by the formation of the chlorruthenate, $\mathrm{X}_{2} \mathrm{RuCl}_{6}$ (or bromruthenate).

This then affords us a simple means of preparing the chlorruthenates. Through a cold, concentrated solution of the "aquo" chlorruthenate, preferably with considerable excess of hydrochloric acid, is led a rapid stream of chlorine. The solution immediately darkens, becoming intense brown with a yellowish cast, and, if sufficiently concentrated, the chlorruthenate is precipitated in minute black octahedra. After being dried on a tile, the dark

1 Miolati and Taziuri : Gazz. chim. ital. 30, II, s!l (1)o ) .

$\because$ C. S. I.ind: Thesis, Mass. Inst. Tech., Ior.z. 
crystalline powder has a peculiar greenish sheen, which is unique among the halide compounds of ruthenium, and which serves to identify the salt, if moderately pure.

The potassium, ammonium, rubidium, and cesium chlorruthenates, $\mathrm{K}_{2} \mathrm{RuCl}_{6},\left(\mathrm{NH}_{4}\right)_{2} \mathrm{RuCl}_{6}, \mathrm{Rb}_{2} \mathrm{RuCl}_{6}$, and $\mathrm{Cs}_{2} \mathrm{RuCl}_{6}$, have been thus prepared, as well as several bromruthenates, which will be described in a later paper. The method of preparation is thus general. In the case of the very sparingly soluble rubidium and cesium salts the preparation is easy; for the more soluble potassium salt, considerable concentration of solution is necessary, while for the ammonium salt the conditions must be carefully adjusted, both in view of the decided solubility of the salt, and the action of the chlorine upon the ammonium. Though succeeding once in preparing a salt which was nearly pure, other attempts resulted in failure.

The series of chlorruthenium salts thus far known is as follows:

$$
\begin{aligned}
& { }^{1} \mathrm{Na}_{2} \mathrm{RuCl}_{5} \\
& { }^{1} \mathrm{~K}_{2} \mathrm{RuCl}_{5} \\
& { }^{1}\left(\mathrm{NH}_{4}\right)_{2} \mathrm{RuCl}_{5}
\end{aligned}
$$$$
{ }^{2} \mathrm{~K}_{2} \mathrm{RuCl}_{5}, \mathrm{H}_{2} \mathrm{O}
$$$$
\mathrm{Rb}_{2} \mathrm{RuCl}_{5}, \mathrm{H}_{2} \mathrm{O}
$$$$
\mathrm{Cs}_{2} \mathrm{RuCl}_{5}, \mathrm{H}_{2} \mathrm{O}
$$$$
\mathrm{K}_{2} \mathrm{Ru}\left(\mathrm{OH}_{2}\right) \mathrm{Cl}_{5}
$$$$
\text { ( } \left.\left.\mathrm{Na}_{4}\right)_{2} \mathrm{Ru}_{2} \mathrm{OH}_{2}\right) \mathrm{Cl}_{5}
$$$$
\begin{aligned}
& { }^{3} \mathrm{Rb}_{2} \mathrm{Ru}\left(\mathrm{OH}_{2}\right) \mathrm{Cl}_{5} \\
& \mathrm{Cs}_{2} \mathrm{Ru}\left(\mathrm{OH}_{2}\right) \mathrm{Cl}_{5}
\end{aligned}
$$$$
{ }^{6} \mathrm{Na}_{2} \mathrm{Ru}(\mathrm{NO}) \mathrm{Cl}_{5}, 3 \mathrm{H}_{2} \mathrm{O}
$$$$
{ }^{6} \mathrm{~K}_{2} \mathrm{Ru}(\mathrm{NO}) \mathrm{Cl}_{5} 2 \mathrm{H}_{2} \mathrm{O}
$$$$
{ }^{6}\left(\mathrm{NH}_{4}\right)_{2} \mathrm{Ru}(\mathrm{NO}) \mathrm{Cl}_{5}, 2 \mathrm{H}_{2} \mathrm{O}
$$$$
\mathrm{Rb}_{2} \mathrm{Ru}(\mathrm{NO}) \mathrm{Cl}_{5}, 2 \mathrm{H}_{2} \mathrm{O}
$$$$
\mathrm{Cs}_{2} \mathrm{Ru} \text { (NO) } \mathrm{Cl}_{5}, 2 \mathrm{H}_{2} \mathrm{O} \text {. }
$$

In addition to the above, several other salts have been described, which are not well defined and may be mixtures.

It is interesting to note that Wintrebert ${ }^{7}$ has prepared salts of the series $\mathrm{X}_{2} \mathrm{OsO}_{2} \mathrm{Cl}_{4}$, called by him osmyl chlorides, which correspond to the series $\mathrm{X}_{2} \mathrm{RuO}_{2} \mathrm{Cl}_{4}$, which $\mathrm{I}$ have called oxychlorruthenates. The nomenclature I have used in my papers is open to the criticism of being inconsistent, but it has been transitional; I have delayed proposing a consistent nomenclature until the salts of bivalent ruthenium could be prepared, a hope that seems near realization. Wintrebert has also described salts of the type

1 Claus.

2 Miolati : Loc. cit. Verified by H. B. Graybill in this laboratory.

${ }^{3}$ A later examination has shown that the salt from which analysis 18 (this Journal, 23, 786) was made, was the "aquo" chlorruthenate.

4 Antony.

5 Described by Claus as $\mathrm{K}_{2} \mathrm{RuCl}_{6}$ and $\left(\mathrm{NH}_{4}\right)_{2} \mathrm{RuCl}_{6}$. Correct composition shown by Joly.

- Joly.

7 Wintrebert: Thesis, Bordeaux, 1902 . 
$\mathrm{X}_{2} \mathrm{OsO}_{3} \mathrm{Cl}_{3}$, no ruthenium analogues of which have as yet been prepared.

Reference should be made to the first chlorruthenate, $\mathrm{K}_{2} \mathrm{RuCl}_{6}$, which was prepared by Antony, and which from its properties appears to belong to a different series from the chlorruthenates prepared by the action of chlorine upon the "aquo" chlorruthenates. As the description of this salt and its preparation has not appeared in a readily accessible journal, I venture to translate the description which Professor Antony was kind enough to write out for me in detail.

"I have prepared the chlorruthenate of potassium, by heating to fusion 6 parts of sodium hydroxide with I part of absolutely pure ruthenium; small portions of potassium chlorate were added till the ruthenium was completely dissolved. The melt was then heated until the excess of chlorate was wholly decomposed, and allowed to cool. Very dilute hydrochloric acid was then added, the whole being kept cold. If the chlorate has been completely decomposed, there is no evolution of ruthenium tetroxide. The liquid cannot be warmed without decomposition, but when evaporated in a vacuum over sulphuric acid, it deposits red-brown crystals of the chlorruthenate, almost insoluble in the potassium chloride solution, somewhat soluble in cold water, and very soluble with decomposition in warm water. Analysis gave the following figures:

\begin{tabular}{|c|c|}
\hline $\begin{array}{l}\text { Found. } \\
\text { Per cent. }\end{array}$ & $\begin{array}{c}\text { Calculated for } \mathrm{K}_{2} \mathrm{RuC}_{1 ;} \text {. } \\
\text { Per cent. }\end{array}$ \\
\hline Chlorine (with ruthenium) $\ldots \ldots \quad 36.074$ & 36.109 \\
\hline$z \mathrm{Cl} \ldots \ldots \ldots \ldots \ldots \ldots \ldots \ldots \ldots \ldots \ldots .637 .936$ & 37.993 \\
\hline Ruthenium ............. 25.912 & 25.897 \\
\hline Total chlorine............. 54.146 & $54.163 . "$ \\
\hline
\end{tabular}

It will be noted that the two chlorruthenates differ in color and solubility, that of Antony being red-brown and only slightly soluble in cold water, while that which I have prepared is black with a greenish sheen, and is very soluble and rapidly decomposed by cold water. It appears with our present light as if there were among the chlorides of ruthenium three pairs of isomers, viz.:

$\begin{array}{ll}\mathrm{K}_{2} \mathrm{RuCl}_{5}, \mathrm{H}_{2} \mathrm{O} & \text { Monohydrated chlorruthenite, } \\ \mathrm{K}_{2} \mathrm{Ru}\left(\mathrm{OH}_{2}\right) \mathrm{Cl}_{5} & \text { "Aquo" chlorruthenate : } \\ \mathrm{K}_{2} \mathrm{RuCl}_{5} & \text { Chlorruthenite, } \\ \mathrm{K}_{2} \mathrm{RuCl}_{5} & \text { Dehydrated "aquo" chlorruthenate; } \\ \mathrm{K}_{2} \mathrm{RuCl}_{5} & \text { Chlorruthenate from } \mathrm{K}_{2} \mathrm{RuO}+\mathrm{HCl}_{4}, \\ \mathrm{~K}_{2} \mathrm{RuCl}_{6} & \text { Chlorruthenate from } \mathrm{K}_{2} \mathrm{Ru}\left(\mathrm{OH}_{2}\right) \mathrm{Cl}_{5}+\mathrm{Cl}\end{array}$


EXPERIMENTAL PART.

The analyses of the following salts were carried out as has been described in the previous paper.

Potassium Aquochlorruthenate, $\mathrm{K}_{2} \mathrm{Ru}\left(\mathrm{OH}_{2}\right) \mathrm{Cl}_{5}$.-Prepared by boiling a slightly acidified (with $\mathrm{HCl}$ ) solution of $\mathrm{K}_{2} \mathrm{RuCl}_{5}$ with alcohol, or the hydrated sesquioxide, $\mathrm{Ru}_{2} \mathrm{O}_{3}$, with hydrochloric acid and alcohol. The complete conversion of the salt requires several hours' boiling and is noticeable by the solution becoming much lighter in color and losing all trace of a yellowish cast, having a clear rose-red shade. The salt crystallizes, on evaporation, in apparently orthorhombic octahedra, showing often base and prism faces. It is quite soluble in water, bearing considerable dilution before slowly hydrolyzing. On boiling, the solution darkens to a greenish brown, but gives no immediate precipitate. This darkened solution does not change immediately on addition of hydrochloric acid (distinction from the chlorruthenates) but gradually becomes yellower with a cast of red. The characteristic reaction of the salt is the immediate darkening of its solution on addition of bromine or chlorine water. With alkalies its solution gives a dirty white precipitate which soon becomes black, differing thus from the solutions of the trichloride, which give an immediate black precipitate. The other reactions of the salt, as far as examined, are common to all ruthenium chloride solutions.

( I) 0.3927 gram salt. Lost no water at $90^{\circ}$.

(2) 0.4792 gram salt. The water in this analysis was determined by absorption in a $\mathrm{P}_{2} \mathrm{O}_{5}$ tube, the salt being heated in a stream of air, and a coil of silver being used to hold the chlorine evolved.

(3) 0.4335 gram salt. The loss of water by the desiccatordried salt was as follows:

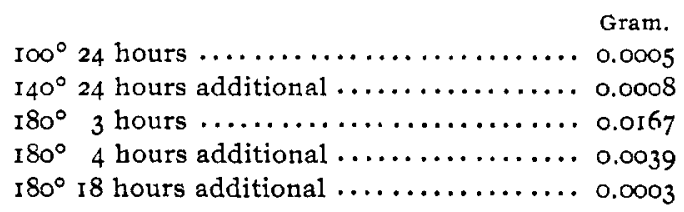

The salt is thus stable up to $140^{\circ}$, but loses its water between $140^{\circ}$ and $180^{\circ}$. 
JAS. LEWIS HOWE.

\begin{tabular}{|c|c|c|c|}
\hline (1) & $\begin{array}{c}(2) \\
\text { Per cent. }\end{array}$ & Per cent. & $\begin{array}{l}\text { Theory, } \\
\text { Per cent }\end{array}$ \\
\hline 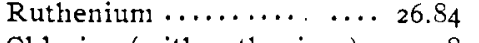 & & $\cdots$ & 27.09 \\
\hline Chlorine (with ruthenium) $\cdot 27.7^{8}$ & $\cdots$ & $\cdots$ & 28.35 \\
\hline Potassium $\ldots \ldots \ldots \ldots \ldots \ldots .20 .63$ & $2 \mathrm{I} \cdot \mathrm{I} 3$ & ... & 20.85 \\
\hline Chlorine (with polassium) $\ldots \quad 18.67$ & I9.14 & .... & 18.90 \\
\hline Water .................. & 6.07 & 4.82 & 4.80 \\
\hline
\end{tabular}

Ammonium Aquochlorruthenate, $\left(\mathrm{NH}_{4}\right)_{2} \mathrm{Ru}\left(\mathrm{OH}_{2}\right) \mathrm{Cl}_{5}$.-Prepared by boiling $\left(\mathrm{NH}_{4}\right)_{2} \mathrm{RuCl}_{5}$ with dilute acidified alcohol. The crystals obtained on evaporation were far from uniform and it was difficult to get satisfactory material for analysis. The only satisfactory method of analysis was heating the salt with lime and determining the chlorine by dissolving out the $\mathrm{CaCl}_{2}$ formed. There seems to be some evidence of the presence of a salt, $\mathrm{NH}_{4} \mathrm{Ru}\left(\mathrm{OH}_{2}\right) \mathrm{Cl}_{4}$ (i. e., $\left.\mathrm{NH}_{4} \mathrm{Cl}, \mathrm{Ru}\left(\mathrm{OH}_{2}\right) \mathrm{Cl}_{3}\right)$, as in several analyses ruthenium to the amount of about 37 per cent. (theory 36.39 per cent.) was found, but the existence of this salt could not be established. All the solutions showed the aquo salt reaction with bromine.

(4) 0.4400 gram salt. By lime method.

(5) 0.2537 gram salt. Stable at $145^{\circ}$; lost in 34 hours at $200^{\circ}$ $0.0120 \mathrm{gram}$; in 24 hours further heating $0.0025 \mathrm{gram}$; no further loss on heating at $200^{\circ}$.

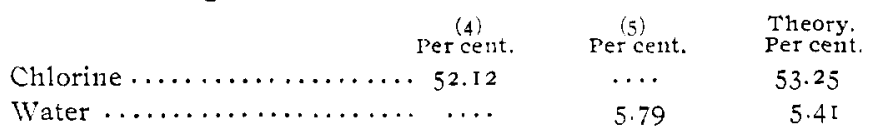

Potassium Chlorruthenate, $K_{2} R u C l_{6}$-Prepared by the action of chlorine on concentrated, acid solution of $\mathrm{K}_{2} \mathrm{Ru}\left(\mathrm{OH}_{2}\right) \mathrm{Cl}_{5}$. Minute black octahedra, with greenish sheen. Easily soluble and rapidly decomposed by water, giving pale purplish brown solution on boiling, which is given a fugitive deep purple by addition of concentrated hydrochloric acid. This is the only characteristic reaction which has been found for the chlorruthenates. Dilute solution in hydrochloric acid is pure yellow, concentrated solution deep yellowish red.

(6) 0.2585 gram salt.

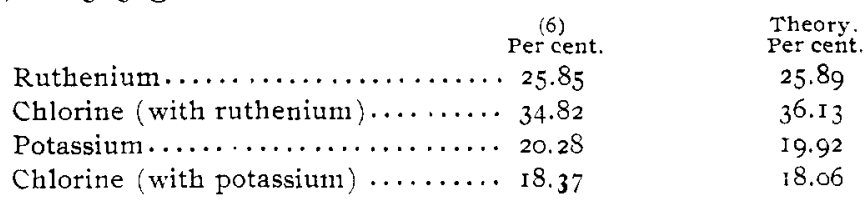


Ammonium Chlorruthenate, $\left(\mathrm{NH}_{4}\right)_{2} \mathrm{RuCl}_{0}$-Prepared by action of chlorine on a concentrated solution of the aquo salt. Tile dried but very difficult to free from the mother-liquor. Resembles in every respect the potassium salt except that it is more soluble.

(7) 0.2 I29 gram salt. Considerable of the lower chloride present.

(8) o.I543 gram salt. An attempt was made to separate the chlorine attached to the ruthenium by a hydrogen stream and let the ammonium chloride sublime on the tube. A little of the vapor of the ammonium chloride passed on and failed of absorption in the silver nitrate solution. The ratio $\mathrm{Ru}: \mathrm{Cl}$ was $\mathrm{I}: 3.6$, showing as in 7 (same crop of crystals) that considerable of the lower chloride was present.

(9) 0.4812 gram salt. Lime method. Ruthenium recovered and heated in hydrogen after solution of the lime.

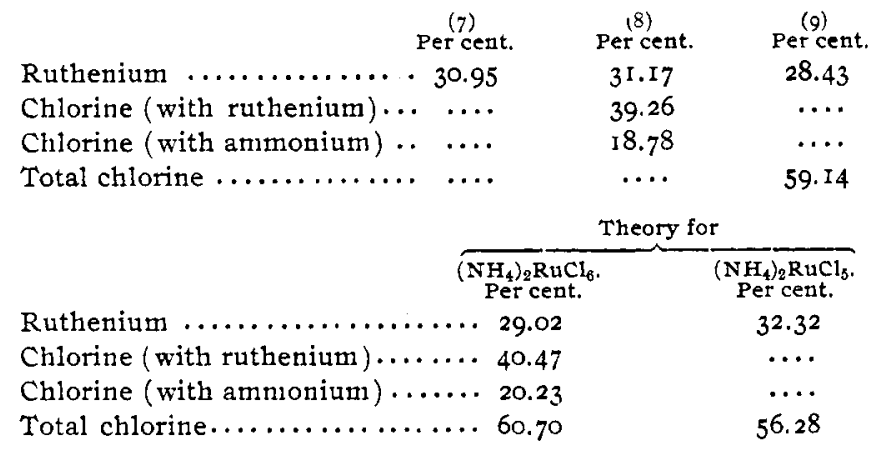

Cesium Chlorruthenate, $\mathrm{Cs}_{2} \mathrm{RuCl}_{3}$. - It is well to add this anal$y$ sis of the salt prepared by the action of chlorine on a solution of the aquochlorruthenate.

(I0) 0.3338 gram salt.

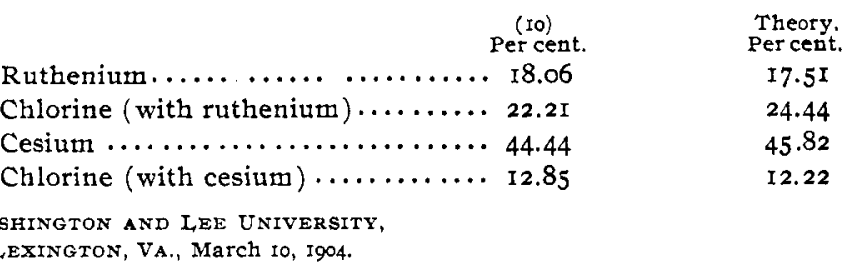

